\title{
The Analysis Effect of Traffic Acces at AH. Nasution and STM Street
}

\author{
Marwan Lubis $^{1}$, Darlina Tanjung ${ }^{1}$, Hamidun Batu Bara ${ }^{1}$, M. Husni Malik Hasibuan ${ }^{1}$, Abdurrozzaq Hasibuan ${ }^{2}$ \\ ${ }^{1}$ Department of Civil Engineering, Faculty of Engineering, Universitas Islam Sumatera Utara, Medan, Indonesia \\ ${ }^{2}$ Department of Industrial Engineering, Faculty of Engineering, Universitas Islam Sumatera Utara, Medan, Indonesia \\ *Corresponding author E-mail: Azmi.rizki@ft.uisu.ac.id
}

\begin{abstract}
The impact of the construction of an activity center will create awakening and attraction traffic and also increase negative impact to the flow of traffic access, safety, comfortable to pedestrian, the surrounding will be influenced by building development or building activities. The analysis result has been done is know the V/R ratio of street especially at segment 4 in 2019. The ratio of the service indicators is at level E. Instability condition of the traffic access that often stop with the average speed of the vehicle about $28.5 \mathrm{~km} / \mathrm{h}$, while the volume road performence in 2024 or after the student's building has operated about 5 years was predicted the service indicators is at level F, its mean forced flows or jammed, low speed capacity and long vehicle and became a big obstacle, while another access is at e level especially at segment 2 for A $\mathrm{H}$ Nasution access and segment 3 at STM street access.
\end{abstract}

Keywords: Traffic Access, Awakening and Attracrion Traffic

\section{Introduction}

The traffic congestion problem will disadvantage of traffic' user like waste fuel and spend much time on the way. To minimize this problem, its better to do the analysis of traffic impact to construction, some center activities especially something that giving important effect to city street access system which correspanding permen no 75 2016[1], [2]. The impact of center activities building will cause awakening and attraction traffic, so it can burdening and influencing social human life and of course will give negative impact to:

1. Smoothness traffic not only for motor vehicle but also pedestrian.

2. Pedestrian' safety will be distrub resulting from rise of traffic flow.

3. The comfortable of the road's user is related the decrease of the speed vehicle, the increase of noise and the decrease of the air quality due to the exhaust generated by the rise of traffic flow to the development.

4. The endurance declining street, which is caused by burdening traffic on type and amount of motor vehicle which is passed on the street and also for the construction of street pavement.

5. A viewing from an object of traffic will influence a viewing disturbance of one side to another side of the road section

Some analysis that must be done are existing and predicting of traffic condition in the future by predicting amount of awakening spreading and burdening trip in the future and also evaluate the negative effect which is caused by its building it self[3].

\section{Purpose And Goal}

This research is expected to provide problem solving, alternative that might be inflicted like :

1. To evaluated the extend to which the impact are generated by the growth of development and activities that like medicinal activities of UISU, shop in Medan city especially at STM street.

2. To minimize the effect that might be caused by the activities of UISU medical faculty.

The Reseach Scope from this area,especially area that has predicted has influence by there are some activities of medical faculty in UISU at STM street,the scope are[4], [5] :

Area's survey is used to get this condition like:

a. The field survey to get that moment condition are:

- Classified traffic survey at intersections and road segments.

- Survey of vehicle average speed

b. The activies location

The activities location is focused to road segment that is included in the area of road area which will be estimated the impact of campus activities at STM street.

There are some analysis steps to reach the goals

a. Working preparation

b. Doing survey

c. Identifying problems

d. Giving some indicative ideas to the problems

\section{Methodology}

Transportation need in Medan city now days are increasingly are combined by an increasing better economy. there are many private 
transportation that cause increasingly of traffic value especially in the morning and afternoon that cause by some movement. Access a volume of traffic may result in lost for transportation user's, both material loss and increase over rational cost and also spend much time on the way[6], [7].

\section{Data Colection}

Instantional methode or seconder data colection is colection data by visiting the related agencies to get seconder data[3], [7]. The colected data in this steps are:

a. Geometric Data of segment and intersection

b. Data on the lane area under the consetion and designation area Primary data colection is used to get traffic colection data in quantified need to be surveyed directly :

1. Inventory Survey

2. Colection Traffic Flow Survey

3. Speed Survey

\section{Apporoching and Transportation Type}

Model macro approching is started by assesment of land intesting using at STM street and existing traffic condition arround planning primes one survey and skunder for then more, the estimated trip generation, distribution, mode selection and loading of traffic on the road arround the location. Modeling transportation system for analytingtransfort request covering 4 steps of pleanning transformation[8].

1. Trip Generation/Attraction

There are 4 methods :

a. Using main principles

b. Using formulae

c. Uusing complex models

d. Casing comparison method

There are some Factors that must estimate as a free variable that influence the travel magnitudes with the assumption that travelling in unnormal distribution to casual model. The analysis stages of regression model are :

a. Calculated and studied the free variable that is used base on significant train

b. Focused on relation between free variable with non free variable and relation same free variable

c. Trained vality relation using statistic

2. Trip Distribution

Trip distribution is a planning transportation process that has relation with amount of trip for every move meant direction from observing area with the main goal in that zone.

3. Modal Split Election

There are 2 kinds of approaching concepts to do the modal split stage. Trip End Model and Trip Interchange Modal Split Model. In generally, some factors that influenced modal election are

a. Trip characteristic

b. Trip model characteristic

c. Transportation characteristic systems

Moda election model is based on position in sequence analysis as Jhon Black said "urban transport planning" Croom Helm London page 84 model election are classified for 4 categories:

a. The combination with awakening trip

b. Pre-distribution

c. The combination with trip distribution. (gravity type model).

d. Interchange model

4. Traffic Assignment

In outline of loading traffic method, there are some category. as (educational and training DIV Land transportation, DTRDPTPK," city transportation planing', [9]-[11]

a. Free/all or nothing assigment

b. Stochastic or multi path assigment c. (user) eguilibirium assigment

d. Stochastic (user) equilibrium assignment.

\section{Activity Location and Suitability Location Activity with RDTK Medan City}

From administration the planning is located at STM street, Suka Maju district, medan johor, north sumatra.

From geografist the planning is located on coordinate of $3^{\circ} 32^{1} 26.26^{11} \mathrm{~N}$ and $98^{\circ} 41^{1} 25.86^{11} \mathrm{E}$. This is the location of research planning

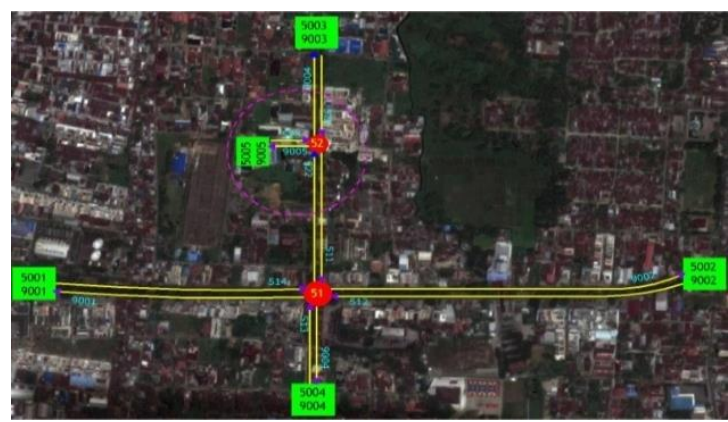

Fig 1: Location Map

\section{The Condition of Land Using Around the Activities}

The condition of land using around the activities site based on research result at pleanning location that can be illustrated at picture below can be known that land use arround the location is residential building, offices, tradings and services. The nearest acsess to that building is STM street. The visualization of land user condition of the researth area canbe seen in the figure

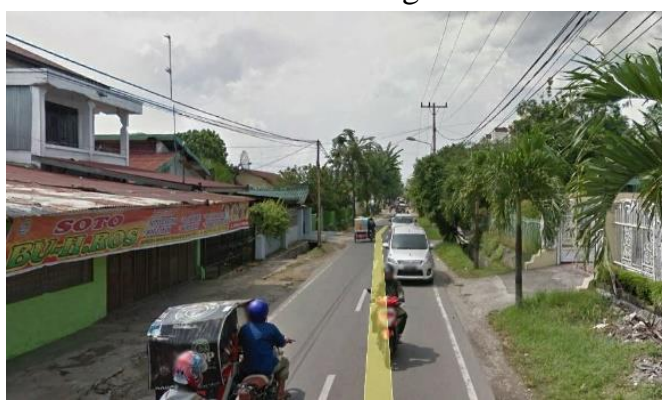

Fig 2: landuser arround STM street

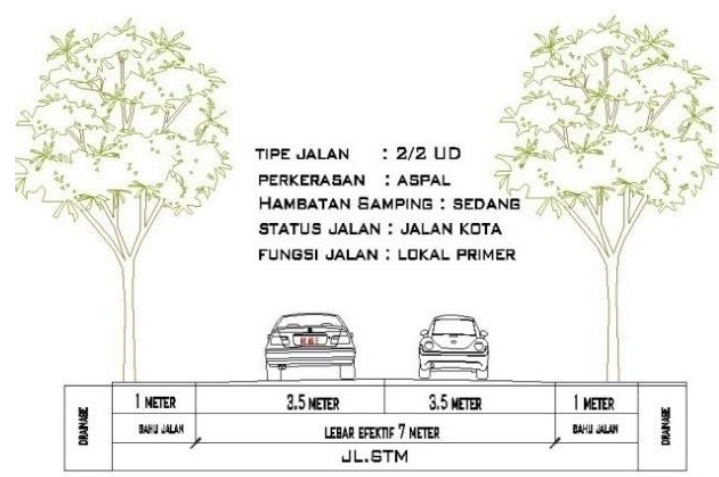

Fig 3: Geometri Capasity STM Street

\section{The Evalualition of Transportasion Infrastructure Data Geometrik Traffic}

Based on research of STM street widh is 7 meter, 2/2 UD, based on RDTR Medan city. The planning of advance of STM street is 
16 meter with GSB 10 meter. The nearer of main juction from location directly infact from that condition is STM Street. This is the trafic Geomatric of STM street.

Table 1: The road geometry at STM street.

\begin{tabular}{|c|c|}
\hline \multicolumn{2}{|c|}{ The Road Geometry Data } \\
\hline Road type & 2 lajur tak terbagi (2/2 UD) \\
\hline 2. $\quad$ Traffic width & 3,5 meter per lajur \\
\hline $\begin{array}{l}\text { 3. Shoulder width is effective } \\
\text { On both side }\end{array}$ & $\pm 1 \mathrm{~m}$ \\
\hline Pavement type & Aspal \\
\hline 5. street statue & city street \\
\hline street class & III \\
\hline \multicolumn{2}{|l|}{ TRAFFIC DATA } \\
\hline 1. Direction distribution & $100 \%(50 \% / 50 \%)$ \\
\hline \multicolumn{2}{|l|}{ City Data Measurement } \\
\hline 1.Population amount & 1-3 billion population \\
\hline \multicolumn{2}{|l|}{ Side obstacles Data (medium) } \\
\hline 1. Many vehicle stop or park & Low \\
\hline 2. Many pedestrian & Low \\
\hline $\begin{array}{l}\text { 3. Many vehicles access from road } \\
\text { side low }\end{array}$ & Medium \\
\hline 4. Many vehicles park or stop & Low \\
\hline 5. Environment condition & offices,trade and services \\
\hline
\end{tabular}

\section{Traffic Capasity}

The capasity accountant used formula of road manual capasity book of Indonisia in 1997 is :

\section{$\mathrm{C}=\mathrm{Co} \times \mathrm{FCw} \times \mathrm{FCsp} \times \mathrm{FCsf} \times \mathrm{FCcs}(\mathrm{smp} /$ Hour $)$}

Table 2: Traffic Information

\begin{tabular}{|l|l|}
\hline Traffic Name & STM Street \\
\hline Rood Type & $2 / 2$ UD \\
\hline Basic Capasity & 2900 \\
\hline
\end{tabular}

\begin{tabular}{|l|l|}
\hline Width Street Factor (FCW) & 1 \\
\hline Bounderies direction factor (FCSP) & 1 \\
\hline Obstacles side factor (FCFS) & 1 \\
\hline City Measurement Factor (FCCS) & 0,92 \\
\hline Capasity C & 2668 \\
\hline Capasity per direction & 1334 \\
\hline
\end{tabular}

From table above has been known that total traffic capasity of STM street is $2668 \mathrm{SMP} /$ hour. caused of split direction of STM street so the capasity per STM street is $1334 \mathrm{SMP} /$ hour

\section{Traffic Volume}

To know the traffic characteristic then surveyed traffic on one of the road segment arround the development buiding for 12 hous from $06.00-18.00$. At the location of the road paln carried out by the traffic enumeration survey at the top hours of traffic,The traffic data from the road segment are as follows :

\section{Traffic Volume Fluctuation Of STM Street}

\section{0 \\ 400 \\ 0}

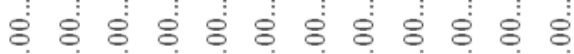

○

The direction of the road Abdul Haris Nasution The direction of the road Sakti Lubis

Fig 4: Traffic Volume Fluctuation of STM Street

Table.3: Performance of rood segment with the contruction of single flats 2019

\begin{tabular}{|c|c|c|c|c|c|c|}
\hline No Link & Link Construction & Capacity & $\begin{array}{c}\text { Volume } \\
\text { (Smp/Hour) }\end{array}$ & VCR & $\begin{array}{l}\text { Speed Rate } \\
(\mathrm{Km} / \text { Hour })\end{array}$ & $\begin{array}{c}\text { Level of } \\
\text { Service }\end{array}$ \\
\hline 511 & STM road segment 1 & 1334 & 1040 & 0.78 & 29.1 & $\mathrm{D}$ \\
\hline 512 & AH. Nst street segment 1 & 3135 & 1932 & 0.62 & 28.3 & $\mathrm{C}$ \\
\hline 513 & STM road segment 2 & 1334 & 668 & 0.50 & 32 & $\mathrm{C}$ \\
\hline 514 & AH. Nst street segment 2 & 3135 & 2144 & 0.68 & 28.7 & $\mathrm{C}$ \\
\hline 521 & STM road segment 3 & 1334 & 854 & 0.64 & 28.1 & $\mathrm{C}$ \\
\hline 522 & STM road segment 4 & 1334 & 1143 & 0.86 & 28.5 & $\mathrm{E}$ \\
\hline 523 & Access road Faculty of Medical UISU & 747 & 275 & 0.37 & 26.4 & B \\
\hline
\end{tabular}

Table.4: Performance of rood segment without the contruction of single flats 2019

\begin{tabular}{|c|c|c|c|c|c|c|}
\hline No Link & Link Construction & Capacity & $\begin{array}{c}\text { Volume } \\
\text { (Smp/Hour) }\end{array}$ & VCR & $\begin{array}{l}\text { Speed Rate } \\
\text { (Km/Hour) }\end{array}$ & $\begin{array}{l}\text { Level of } \\
\text { Service }\end{array}$ \\
\hline 511 & STM road segment 1 & 1334 & 1051 & 0.79 & 29 & $\mathrm{D}$ \\
\hline 512 & AH. Nst street segment 1 & 3135 & 1937 & 0.62 & 28 & $\mathrm{C}$ \\
\hline 513 & STM road segment 2 & 1334 & 668 & 0.50 & 32 & $\mathrm{C}$ \\
\hline 514 & AH. Nst street segment 2 & 3135 & 2150 & 0.69 & 28 & $\mathrm{C}$ \\
\hline 521 & STM road segment 3 & 1334 & 855 & 0.64 & 27 & $\mathrm{C}$ \\
\hline 522 & STM road segment 4 & 1334 & 1154 & 0.87 & 27 & $\mathrm{E}$ \\
\hline
\end{tabular}

Table.5: Performance of rood segment with the contruction of single flats 2024

\begin{tabular}{|c|c|c|c|c|c|c|}
\hline No Link & Link Construction & Capacity & Volume (Smp/Hour) & VCR & $\begin{array}{l}\text { Speed Road } \\
(\mathrm{Km} / \text { Hour })\end{array}$ & $\begin{array}{l}\text { Level of } \\
\text { Service }\end{array}$ \\
\hline 511 & STM road segment 1 & 1334 & 1405 & 1.05 & 13.4 & $\mathrm{~F}$ \\
\hline 512 & AH. Nst street segment 1 & 3135 & 2610 & 0.83 & 25.2 & $\mathrm{D}$ \\
\hline 514 & AH. Nst street segment 2 & 3135 & 2896 & 0.92 & 25.6 & $\mathrm{E}$ \\
\hline 521 & STM road segment 3 & 1334 & 1153 & 0.86 & 24 & $\mathrm{E}$ \\
\hline 522 & STM road segment 4 & 1334 & 1543 & 1.16 & 9.2 & $\mathrm{~F}$ \\
\hline 523 & Access road Faculty of Medical UISU & 747 & 372 & 0.50 & 24.4 & $\mathrm{C}$ \\
\hline
\end{tabular}


Table.6: Performance of rood segment without the contruction of single flats 2024

\begin{tabular}{|c|c|c|c|c|c|c|}
\hline No Link & Link Construction & Capacity & Volume (Smp/Hour) & VCR & $\begin{array}{c}\text { Speed Road } \\
(\mathrm{Km} / \text { Hour })\end{array}$ & Level of Service \\
\hline 511 & STM road segment 1 & 1334 & 1419 & 1.06 & 6.1 & $\mathrm{~F}$ \\
\hline 512 & AH. Nst street segment 1 & 3135 & 2617 & 0.83 & 25.2 & $\mathrm{D}$ \\
\hline 514 & AH. Nst street segment 2 & 3135 & 2905 & 0.93 & 25.1 & $\mathrm{E}$ \\
\hline 521 & STM road segment 3 & 1334 & 1154 & 0.87 & 23.1 & $\mathrm{E}$ \\
\hline 522 & STM road segment 4 & 1334 & 1560 & 1.17 & 2.6 & $\mathrm{~F}$ \\
\hline 523 & Access road Faculty of Medical UISU & 747 & 390 & 0.52 & 24.8 & $\mathrm{C}$ \\
\hline
\end{tabular}

\section{Speed Rate}

Using speed working that was gotten from spot speed survey will be gotten Speed Rate.Like this table below:

Table 6: Vehicle Speed Rate at STM Street

\begin{tabular}{|c|l|c|c|c|}
\hline No & \multicolumn{1}{|c|}{\begin{tabular}{c}
\multicolumn{1}{|c|}{ Ruas } \\
Jalan
\end{tabular}} & \multicolumn{3}{|c|}{ Speed Road (Smp/Hour) } \\
\hline 1 & $\begin{array}{l}\text { STM Road to AH Nasution } \\
\text { Road }\end{array}$ & 31 & 33 & 30 \\
\hline 2 & STM Road to Sakti Lubis Road & 31 & 33 & 30 \\
\hline
\end{tabular}

From the table above has been known that vehicle of speed rate at stm street ,the lowest happened at afternoon .

\section{Moda Election}

From the highest traffic survey classification has been known the traffic volume persentage per a kind moda as follows:

1. Truck/Big bus $=2 \%$

2. Truck/Medium bus $=2 \%$

3. Public transportation $=7,96 \%$

4. Motorcycle $=47,31 \%$

5. Motor Rickshaw $=3,39 \%$

6. Non-motorrized vehicles Carts,bicycle) $=1.02 \%$

\section{Conclusion}

Based on the analysis that has been done from the analysis research of AH Nasution street and STM street can be calculated as follows :

1. Awakening and pulling trip that can be predicted to awakening trip about $12.5 \mathrm{SMP} /$ hour and can be predicted to pulling trip about $12.5 \mathrm{smp} / \mathrm{hour}$.

2. based on the analysis that has been done was known that the road condition this year 2017 in Medan was happened in STM road. Segment four with the worst done where v/c ratio 0.76 , vehicle speed rate is $29.8 \mathrm{Km} /$ hour and the level of its service is D. Which means close to unstable traffic where almost all of riders will be limited. The services volume relatedtotolerable capacity.

3. based on the result of the analysis that has been done to know the condition of abroad in 2019 where the V/C its ratio is already E. By an average speed of $28.5 \mathrm{~km} /$ hour, the following is a road network performance of 2019.

4. Based on the analysis result that has been done the road volume performance in 2024 or after overated 5 years it can be predicted that STM roadsegment I and segment IV, the level of its service is on $\mathrm{F}$ which means road force or stuck, lost speed under capacity and vehicle queue happened very long. And some big obstacle was happened while another roads is in level one of service E. Is on AH Nasution Street, segment II and STM Street Segment III.

\section{References}

[1] F. Miro, Transportation Planning for College Student, planning, and practtioners. Padang: Erlangga Publisher, 2002.

[2] E. K. Morlok, Agent Teknik and Transportation Planning. Jakarta: Erlangga Publisher, 1988.
[3] F. Greenberg and Jim Hecimovich, Traffic Impact Analisys. 1984.

[4] J. Black, Urban Transport Planning, Theory and Practice. London: Croom Helm Ltd., 1981.

[5] A. Hasibuan et al., "Performance analysis of Supply Chain Management with Supply Chain Operation reference model," vol. 1007, pp. 1-8, 2018.

[6] HCM, Transportation Research Board. Institution of Highway and Transportation, 1996

[7] Ortuzar, D. D. J, and L. . Willumsen, Simpson and Curtin, Guidelines For Traffic Impact Study Prepare. Virginia, 1979.

[8] S. and Koepke, Transportation and Development. 1998.

[9] O. Tamin, Modeling Planning and Transportation Engineering. Bandung: ITB, 2008.

[10] O. Z. Tamin, Modeling Planning \& Transportation Engineering. Bandung: ITB, 2000.

[11] O. . Tamin, Planning and Modeling Transportation: problems example and application. Bandung: Publisher ITB, 2003. 